\title{
Molecular Detection and Phylogenetic Analysis of Cucumber Mosaic Virus Infecting Bhut Jolokia (Capsicum chinense Jacq.) of Assam
}

\author{
Munmi Borah ${ }^{1 *}$, R. Gowtham Kumar ${ }^{1}$ and Sundaresha Siddappa ${ }^{2}$
}

${ }^{1}$ Plant Virology Laboratory, Department of Plant Pathology, Assam Agricultural University, Jorhat, Assam (785 013), India

${ }^{2}$ Division of Crop Improvement, Central Potato Research Institute, Shimla, H.P. (171 001), India

\author{
Corresponding Author \\ Munmi Borah \\ e-mail: mborah56@gmail.com
}

\author{
Article History \\ Article ID: IJEP0320 \\ Received in $31^{\text {st }}$ July, 2019 \\ Received in revised form $18^{\text {th }}$ August, 2019 \\ Accepted in final form 23 ${ }^{\text {rd }}$ August, 2019
}

\begin{abstract}
Prevalence of Cucumber mosaic virus (CMV) in Bhut Jolokia (Capsicum chinense Jacq.) in Assam was confirmed by reverse transcriptionpolymerase chain reaction (RT-PCR). The symptomatic expression of CMV infection onto Bhut Jolokia was confirmed as chlorotic yellow mosaic appearance of the leaves, smaller leaves, reduction of plant growth, mosaic and mottling of infected leaves, leaves showing shoestring or filliform symptom and leaf puckering based on RT-PCR. This is the first report on molecular characterization of CMV in Assam, India. The RT-PCR diagnosis revealed presence of CMV with a band length of 593bp which has been obtained from CMV infected samples. The amplified coat protein gene of CMV was cloned and sequenced. Phylogenetic analysis of coat Protein gene of CMV showed close relatedness with African isolates of sub group IB and other isolates of the world.
\end{abstract}

Keywords: Assam, Capsicum chinense, cucumber mosaic virus, phylogenetic tree, RT-PCR

\section{Introduction}

Bhut Jolokia, considered as third hottest chilli pepper is extensively grown in North Eastern region of India, predominantly in the states of Assam, Nagaland and Manipur (Bosland and Baral, 2007). Bhut Jolokia is also known by other names such as Naga Jolokia, Bih Jolokia, Naga King Chilli. In the recent years the traditional crop of North east India is gaining importance because it has been reported as one of the hottest chilli in the world (Baruah et al., 2014). Bhut Jolokia crop is threatened by a range of plant pathogens and among these, cucumber mosaic virus (CMV) causes severe crop damage, leading to low productivity. In a study conducted in 2012-2014, CMV was detected by DASELISA in 55\% of the Bhut Jolokia fields in Assam state with plants exhibiting mosaic, crinkling, dwarfing and reduced leaf size (Borah et al., 2018; Baruah et al., 2016). Cucumber Mosaic Virus (CMV) belongs to the genus cucumovirus in the family Bromoviridae (Palukaitis and García-Arenal, 2003). It has more broad range and infects more than 1200 plant species across 100 plant families with an average yield loss ranging 10-20\% (Palukaitis and García-Arenal, 2003). CMV has tripartite single-stranded positive sense RNA genome. Transmission of CMV occurs mainly through aphids in a non- persistent manner. It can also be transmitted by mechanical means and through seeds. CMV is categorized into subgroups I and II. Subgroup I was divided into IA and IB based on phylogenetic analysis of coat protein gene. CMV subgroups IA and II are present worldwide, while subgroup IB is originated from Asia (Nagendran et al., 2018). The molecular analysis and determination of the phylogenetic status of viruses is one of the most important steps towards the elucidation of the virus epidemiology and is necessary for the control of plant viral diseases, by introducing appropriate varieties for cultivation by farmers. In this paper, we determine the detection and molecular characterization of Coat Protein gene of CMV isolates obtained from infected samples of Bhut Jolokia from various regions of Assam.

\section{Materials and Methods}

Bhut jolokia plants showing typical mosaic, mottling, puckerinrm, fillifom symptoms were collected from various pockets of Jorhat (Borbheta, Kasogoral, Patiagaon and Hahsara) and Golaghat district (Misamora Khanikar Gaon and Buralikson) of Assam from the farmers field (Table 1). The samples were kept at $-60^{\circ} \mathrm{C}$ in deep freeze with proper labels.

Total RNA was isolated from virus infected symptomatic plants by using Miniscript Nucleospin RNA plant kit method. The integrity and quality of total RNA was checked on $1.2 \%$ Agarose gel electrophoresis apparatus. For the amplification specific gene primers, forward primer D10538 


\begin{tabular}{|c|c|c|c|c|c|}
\hline SI. No. & District & Pockets & $\begin{array}{l}\text { Geographic location of } \\
\text { the area }\end{array}$ & $\begin{array}{l}\text { Infected plants } \\
\text { (total plants } \\
\text { surveyed) }\end{array}$ & $\begin{array}{l}\text { Symptoms observed on infected Bhut } \\
\text { Jolokia plants }\end{array}$ \\
\hline \multirow[t]{4}{*}{1.} & \multirow[t]{4}{*}{ Jorhat } & 1. Borbheta & $26 * 44^{\prime} \mathrm{N}, 94 * 10^{\prime} \mathrm{E}$ & $6(10)$ & \multirow{4}{*}{$\begin{array}{l}\text { (A) Chlorotic yellow mosaic appearance } \\
\text { of the leaves, smaller leaves and reduc- } \\
\text { tion of Plant growth, (B) Mosaic and } \\
\text { mottling of infected leaves, (C) infected } \\
\text { leaves showing shoe-string or filliform } \\
\text { symptom, (D) Puckering of infected } \\
\text { leaves }\end{array}$} \\
\hline & & 2. Kasogoral & $26.7690 * \mathrm{~N}, 94.2371 * \mathrm{E}$ & $4(10)$ & \\
\hline & & 3. Patiagaon & $27.0310^{\circ} \mathrm{N}, 94.7769^{\circ} \mathrm{E}$ & $7(10)$ & \\
\hline & & 4. Hahsara, Tiok & $26.6985 * \mathrm{~N}, 92.4851 * \mathrm{E}$ & $8(10)$ & \\
\hline \multirow[t]{2}{*}{2.} & \multirow[t]{2}{*}{ Golaghat } & $\begin{array}{l}\text { 1. Misamora } \\
\text { Khanikar Gaon }\end{array}$ & $26.7 * \mathrm{~N}, 93.97 * \mathrm{E}$ & $4(10)$ & \multirow{2}{*}{$\begin{array}{l}\text { (A) Mosaic and mottling of infected } \\
\text { leaves, (B) infected leaves showing shoe- } \\
\text { string or filliform symptom, (C) Puckering } \\
\text { of infected leaves }\end{array}$} \\
\hline & & 2. Buralikson & $26 * 44^{\prime} \mathrm{N}, 94^{*} 10^{\prime}$ & $5(10)$ & \\
\hline
\end{tabular}

(5' GCCACCAAAAATAGACCG $3^{\prime}$ ) and the reverse primer $\left(5^{\prime}\right.$ ATCTGCTGGCGTGGATTTCT $3^{\prime}$ ) targeting CP gene, $593 \mathrm{nt}$ of CMV genome were used for PCR. First strand CDNA synthesis was carried out using Applied Biosystems High capacity cDNA Reverse Transcription kit as per manufacturer's instructions. Reactions were formed at $25^{\circ} \mathrm{C}$ for $10 \mathrm{~min}$ followed by $37^{\circ} \mathrm{C}$ for $120 \mathrm{~min}$ and $85^{\circ} \mathrm{C}$ for $5 \mathrm{~min}$. Amplifications were carried out using Emerald PCR master mix (Thermo Scientific) in a thermocycler with initial denaturation of 4 min at $94{ }^{\circ} \mathrm{C}$ followed by 30 cycles of denaturation at $94{ }^{\circ} \mathrm{C}$ for $30 \mathrm{sec}, 53$ ${ }^{\circ} \mathrm{C}$ for $30 \mathrm{sec}, 72{ }^{\circ} \mathrm{C}$ for $40 \mathrm{sec}$ and final extension temperature of $72^{\circ} \mathrm{C}$ for a min. The PCR products were analysed in agarose gel (1.2\%) electrophoresis in 1X TAE buffer containing 200 $\mathrm{ng}$ of ethidium bromide $\mathrm{ml}^{-1}$. The PCR product was eluted and purified by using standard protocol (Machery-Nageli Nucleospin Gel Purification kit). The purified PCR product was ligated into $\mathrm{PTZ57R/T}$ vector (Thermo Scientific) according to the manufacturer's instructions and then transformed into E. coli $\mathrm{DH} 5 \alpha$ and cultured in LB agar media containing 50 $\mathrm{mg} \mathrm{l}^{-1}$ ampicillin for 16 hours at $37^{\circ} \mathrm{C}$ in a shaking incubator. Recombinant colonies were screened by restriction digestion. Plasmids were isolated using kit method (Nucleospin Plasmid DNA Purification Kit). Positive clones were sequenced in 3500 Genetic Analyser Sequencer. Sequences were assembled using CLUSTAL W2 and assembled sequences of Coat Protein gene were deposited in the NCBI database.

\subsection{Phylogenetic analysis}

Nucleotide sequences of $\mathrm{CMV}$ isolates belonging to subgroup IA, IB and II reported from different parts of the world were retrieved from the NCBI database and analyzed using MEGA 6.0 Version.

\section{Results and Discussion}

Characteristic symptoms of Cucumber Mosaic Virus infection onto Bhut Jolokia plants were reported in the fields of Jorhat and Golaghat districts of Assam based on RT-PCR results. The virus disease symptoms on the Bhut Jolokia plants include (A) Chlorotic yellow mosaic appearance of the leaves, smaller leaves and reduction of Plant growth, (B) Mosaic and mottling of infected leaves, (C) infected leaves showing shoe-string or filliform symptom, (D) Puckering of infected leaves (Figure 1). According to Nagendran et al. (2018), CMV on snake gourd
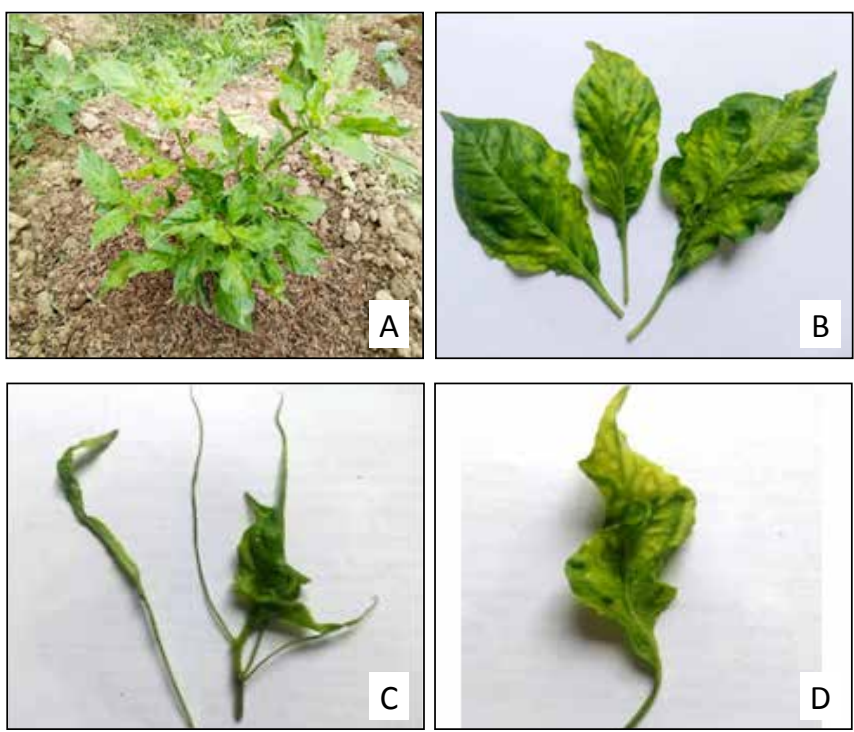

Figure 1: Symptoms of CMV onto Bhut Jolokia crop in field (A) Chlorotic yellow mosaic appearance of the leaves, smaller leaves and reduction of Plant growth, (B) Mosaic and mottling of infected leaves, (C) infected leaves showing shoe-string or filliform symptom, (D) Puckering of infected leaves

and bottle gourd produce mosaic and puckering symptoms on the infected plant. The most characteristic symptom of CMV onto tomato was reported as filiformity or shoestring-like leaf blades by Zitter and Murphy (2009). Similar symptoms of CMV on chilli pepper was reported by Zitter and Murphy (2009) as chlorosis of young leaves, oak leaf patterns (filliform), chlorotic 
mosaic symptom, severe stunting and leaf deformation including sunken interveinal lamina with protruding primary veins (leaf puckering) and symptoms of CMV onto Bhut Jolokia crop plants were reported by Borah et al. (2018).

The host symptoms were confirmed by RT-PCR analysis using CMV coat protein gene specific primer pair. Infected samples generated amplicons of expected size (593bp) in RT-PCR and the sequence data of amplified region confirmed that the virus isolates of CMV were present in samples of Bhut Jolokia (Figure 2). The study established the presence of $\mathrm{CMV}$ in

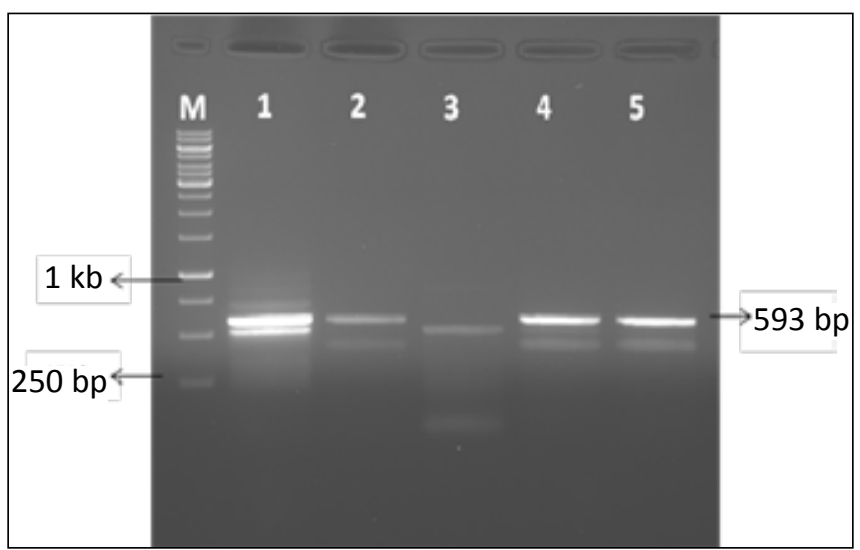

Figure 2: RT-PCR analysis for the amplification of Coat Protein (CP)Gene of CMV infecting Bhut jolokia; Agarose gel electrophoresis showing amplification of 593nt CP gene, with lane M: $1 \mathrm{~kb}$ ladder, lane 1-5: 5 CMV infected Bhut Jolokia samples
Bhut Jolokia plantations in Jorhat and Golaghat districts of Assam. The PCR amplicon obtained for the virus was in band size typically obtained for CMV. The viral origin of the specific amplicon was confirmed by Sanger sequencing.

The sequence analysis by homology searches revealed that the sequences of the isolate have $96 \%$ nucleotide identity with CMV of Africa of Subgroup IB (MG021462.2) (Figure $3)$. The Phylogenetic analysis of Coat Protein (CP) gene of our CMV isolates with other known isolates were closely associated with other known isolates belonging to sub group IA, IB and II revealed that all the CMV isolates were closely associated with the sub group IB and clustered together with CMV isolate of Sub-saharan Africa along with other isolates of world with sub group IB.

Similarly Nagendran et al. (2018) reported the presence of CMV in the virus infected samples of cucurbitaceous crops viz., bottle gourd and snake gourd in areas of Tamil Nadu and found that the virus isolates were found in close resemblance with subgroup of IB. Pratap et al. (2008) categorized the subgroup of CMV strains based on the coat protein sequence analysis infecting tomato in India. Dubey et al. (2008) amplified the coat protein gene of CMV infecting Gladiolus in India through RT-PCR and CP gene sequences of Gladiolus CMV isolate grouped under IA. Infection of tomato with CMV subgroup IA strain of Pakistan by RT-PCR using genus-specific single pair of primers combined with RFLP analysis with different restriction endonucleases was also reported (Anwer et al., 2008). CMV was effectively detected

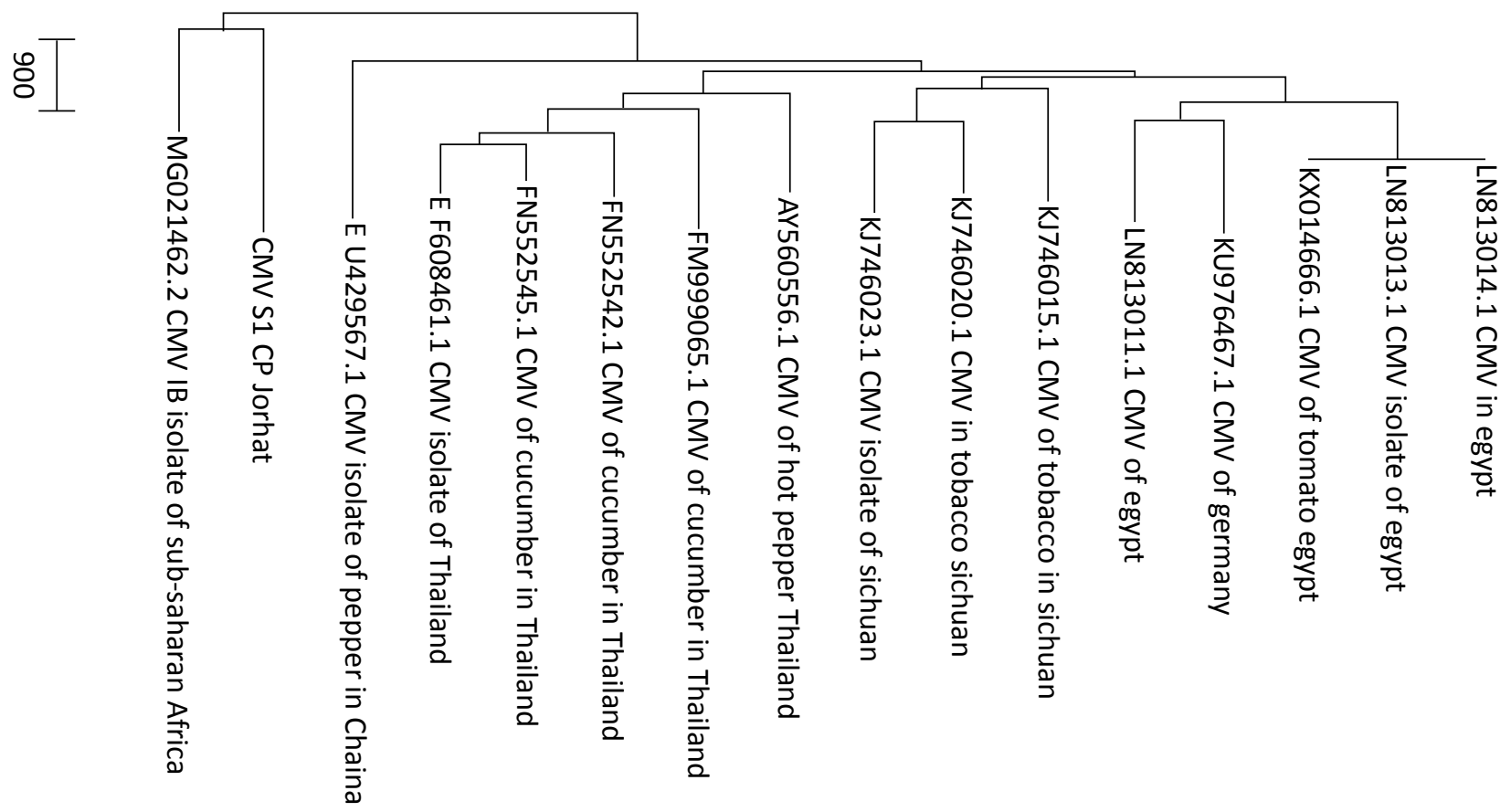

Figure 3: Phylogenetic tree based on Coat-Pretein nucleotide sequences of CMV isolates infecting Bhut Jolokia crops in Assam with other GeneBank accessions showing the different serogroups. Maximum likelihood phylogenetic tree showing relationships among CMV S1 CP Jorhat isolates with other Indian and international CMV isolates using CP gene. Scale bar represent the genetic distance, proportional to the number of nucleotide differences between branch nodes 
with different set of degenerate primers (Hu et al., 1995). Sequence information of the viral genome of CMV infecting Banana in detail and its molecular characterization provided comprehensive sequence information on RNA 1a, RNA 3 and RNA 2b genomic fragments (Vishnoi et al., 2013).

The sequence analysis of these fragments revealed its highest identity and close relationships with Indian strains of subgroup IB. The phylogenetic tree generated with CMV isolates of subgroup IA, IB and II, positioned our CMV isolates infecting Bhut Jolokia in Assam under subgroup IB (Figure 3). Cucumber Mosaic Disease caused by CMV has become an important threat which deteriorate the medicinal property of Bhut Jolokia. The present study also suggests that Cucumber Mosaic Virus may be a serious threat to Bhut Jolokia cultivation in Assam in the near future. In addition, the disease can also have indirect effects by restricting germplasm movement and by predisposing plants to damage by other biotic and abiotic stress factors.

\section{Conclusion}

In conclusions, CMV infecting Bhut Jolokia crop of Assam was successfully identified and characterized based on coat protein gene sequence. This is the first report on molecular characterization of CMV in Assam, India. The Phylogenetic analysis of CMV isolates from different parts of the world will be useful in understanding disease epidemiology and designing suitable management program of this virus.

\section{Acknowledgement}

The Director, ICAR-Central Potato Research Institute (CPRI), Shimla isgratefully acknowledged for allowing Dr Munmi Borah (Jr. Scientist, Plant Pathology, AAU, Jorhat) to conduct a part of this research work at Division of Crop Improvement, Central Potato Research Institute, Shimla 171001, H.P., India.

\section{References}

Anwer, K.P.A., Najeeb, U., Muhammad, Y.S, Hafiza, M.N.C., 2008. First report of cucumber mosaic virus subgroup IB and II isolates infecting tomatoes in Pakistan. Journal of Plant Pathology. https://doi.org/10.1007/s42161019-00242-5.

Baruah, B.R., Kashyap, A., Nath, P.D., 2016. Incidence, detection and integrated management of viral disease complex in Bhut Jolokia, a chilli cultivar in Assam. Annals of Plant Protection Sciences 24, 136-41.

Baruah, S., Zaman, M.K., Rajbongshi, P., Das, S., 2014. A Review on Recent Researches on Bhut jolokia and Pharmacological Activity of Capsaicin. International Journal of Pharmaceutical Sciences Review and Research 24, 89-94.

Borah, M., Berbati, M., Reppa, C., Holeva, M., Nath, P.D., Voloudakis, A., 2018. RNA-based vaccination of Bhut Jolokia pepper (Capsicum chinense Jacq.) against cucumber mosaic virus. Virus Disease 29, 207-211.

Bosland, P.W., Baral, J.B., 2007. Bhut Jolokia - The world's hottest known chilli is a putative naturally occurring inter specific hybrid. Horticultural Science 42, 222-224.

Dubey, V.K., Aminuddin, C., Singh, V.P., 2008. First report of a subgroup IA Cucumber mosaic virus isolate from gladiolus in India. Australasian Plant Diseases Notes 3, 35-37.

Hu, J.S., Li, H.P., Barry, K., Wang, M., Jordan, R., 1995. Comparison of dot blot ELISA and RT-PCR assays for detection of two cucumber mosaic virus isolates infecting banana in Hawaii. Plant Disease 79, 902-906.

Nagendran, K., Priyanka, R., Arvinthraj, R., Balaji, C.G., Swamy, P., Bagewadi, B., Mohan, K.S., Karthikeyan, G., 2018. Characterization of Cucumber Mosaic Virus infecting Snake Gourd and Bottle gourd in India. Physiological and Molecular Plant Pathology 103, 102-106.

Palukaitis, P., Garcia-Arenal, F., 2003. Cucumoviruses. Advances in Virus Research 62, 241-323.

Pratap, D., Kumar, S., Raj, K., 2008. First molecular identification of a Cucumber mosaic virus isolate causing shoestring symptoms on tomato in India. Australasian Plant Disease Notes 3, 57-58.

Vishnoi, R., Susheel, K., Shri, K.R., 2013. Molecular characterization of a cucumber mosaic virus isolate associated with mosaic disease of banana in India. Phytoparasitica 41, 545-555.

Zitter, T.A., Murphy, J.F., 2009. Cucumber mosaic. The Plant Health Instructor. Available from https://www. apsnet.org/edcenter/disandpath/viral/pdlessons/ Pages/Cucumbermosaic.aspx. DOI: 10.1094/ PHI-I-2009-0518-01. 